\title{
PENGEMBANGAN MODEL PROBLEM BASED LEARNING UNTUK MENINGKATKAN PENGUASAAN KONSEP MAHASISWA PGSD PADA MATAKULIAH PENDIDIKAN SAINS SD
}

\author{
Alik Mustafidal Laili ${ }^{1)}$, Eries Norma Yusmita ${ }^{2)}$ \\ ${ }^{1)}$ STKIP PGRI Tulungagung, ${ }^{2)}$ STKIP PGRI Tulungagung \\ ${ }^{1)}$ email:alikmustafidallaili27@gmail.com, ${ }^{2)}$ eriesnorma@ gmail.com
}

\begin{abstract}
Abstrak
Penelitian ini dilatarbelakangi oleh rendahnya penguasaan konsep mahasiswa pada matakuliah SAINS yang disebabkan adanya kelemahan pada sintak Problem Based Leaerning yang mengakibatkan proses pembelajaran pada matakuliah Pendidikan Sains SD kurang optimal. Cara untuk mengatasi kelemahankelemahan tersebut salah satunya dengan memasukkan unsur scaffolding ke dalam sintaks PBL. Penelitian ini bertujuan untuk mendeskripsikan kelayakan model Problem Based Leaerning berbasis procedural scaffolding. Penelitian ini menggunakan penelitian pengembangan dengan model 4-D yang terdiri dari tiga tahap yaitu tahap mengembangkan model Problem Based Learning, tahap validasi dan revisi, dan tahap uji coba dengan menggunakan rancangan one group pretest-posttest design. Teknik pengumpulan data menggunakan angket, validasi, pengamatan, dan tes. Teknik analisis data menggunakan deskriptif kualitatif. Hasil penelitian menunjukkan bahwa: (1) Kelayakan perangkat pembelajaran yaitu RPS, RPP, dan LKS berscaffold, masing-masing diperoleh hasil 4,89; 4,72; dan 4,79 dengan kriteria valid, (2) Respons mahasiswa terhadap LKS berscaffold yaitu tampilan LKS dan isi LKS 82\% menarik; penjelasan LKS 73\% mudah dipahami; sedangkan gambar LKS 77\% mudah dipahami dan (3) Respon positif mahasiswa terhadap pembelajaran Sains berbasis Procedural Scaffolding dengan model Problem Based Learning dengan nilai rata-rata 3,3. Kesimpulnnya model Problem Based Leaerning berbasis procedural scaffolding layak untuk digunakan.
\end{abstract}

Kata Kunci: Model Problem Based Learning, Pendidikan Sains SD, Procedural Scaffolding

\section{Pendahuluan}

Proses belajar mengajar yang diterapkan oleh guru SD masih sangat statis, hanya sekedar mengejar target pencapaian kurikulum yang telah ditentukan dan siswa kurang diajak berpartisipasi secara aktif. Dengan situasi pembelajaran yang statis interaksi guru dengan siswa, serta siswa dengan lingkungan belajarnya menjadi kurang optimal. Akibatnya hal tersebut akan berdampak pada penguasaan konsep dan hasil belajar siswa. Dengan demikian, pendidikan di sekolah dasar (SD) yang diterapkan hendaknya diikuti dengan adanya peningkatan penguasaan konsep yang baik.

Penguasaan konsep merupakan salah satu unsur penting dalam menentukan keberhasilan pembelajaran. Pengusaan konsep membuat siswa mampu mendefinisikan konsep dan mengetahui 
atribut-atribut kritisnya (Arends, 2008 : 342). Dalam konteks pembelajaran konstruktivisme, proses berpikir yang lebih sesuai untuk digunakan dalam pembentukan konsep adalah penalaran induktif. Dalam penalaran induktif, guru memberikan contoh dan bukan contoh tentang suatu konsep, kemudian siswa menemukan dan mencapai konsep itu sendiri (Arends, 2008:332).

Berdasarkan data wawancara dan observasi yang dilakukan kepada guruguru di SD, ditemukan fakta bahwa lulusan program studi PGSD tidak mampu mengarahkan siswa untuk belajar mandiri dan memahami materi Sains SD dengan baik. Guru yang berasal dari lulusan PGSD hanya menjelaskan tanpa memberikan pemahaman dan pengalaman secara langsung kepada siswa untuk mendalami materi. Siswa hanya bisa memahami materi dengan cara menghafal saja sehingga penguasaan konsep yang harus dimiliki siswa kurang maksimal.

Rendahnya penguasaan konsep mahasiswa pada matakuliah SAINS disebabkan oleh faktor model pembelajaran yang digunakan. Salah satu model pembelajaran yang dapat meningkatkkan penguasaan konsep siswa adalah Problem based learning (PBL). PBL dapat meningkatkan penguasaan konsep karena PBL merupakan salah satu model pembelajaran aktif yang ditandai dengan adanya peran aktif siswa dalam belajar (Arends, 2008:51). Hal ini relevan dengan hasil penelitian terdahulu yang menunjukkan bahwa PBL dapat meningkatkan penguasaan konsep siswa lebih baik dibandingkan dengan pembelajaran konvensional (Demirel \& Turan, 2010; Folashade \& Akinbobola, 2009; Selcuk, 2010). Selain itu, PBL juga merupakan salah satu model pembelajaran dengan karakteristik yang sesuai untuk diimplementasikan dalam pembelajaran fisika karena PBL membuat siswa secara aktif mendapatkan pengetahuan melalui penyelesaian masalah secara kelompok (Bilgin, 2009) dan memberikan fleksibilitas dan kebebasan untuk bertukar pendapat dan pandangan dengan teman sekelompoknya (Pepper, 2009). Diskusi kelompok dalam PBL tersebut tampaknya memiliki pengaruh positif terhadap minat siswa dalam materi pelajaran (Dolmans dan Schmidt, 2006). Selain itu, PBL juga menggunakan permasalahan yang didesain oleh guru secara otentik berdasarkan situasi dunia nyata sebagai landasan pelaksanaan pembelajaran (Pepper, 2009). Adanya masalah dalam desain PBL dapat membangkitkan kreativitas dan kemampuan kognitif siswa untuk memecahkan masalah yang disajikan (Hegde \& Meera, 2012). Hasil studi lain juga menunjukkan bahwa desain pembelajaran berbasis masalah dapat memberikan dampak pada peningkatan hasil belajar siswa (Gonen \& Basaran, 2008).

Pelaksanaan PBL dalam proses pembelajaran masih menunjukkan adanya kelemahan-kelemahan. Cara untuk mengatasi kelemahan-kelemahan tersebut salah satunya dengan memasukkan unsur scaffolding ke dalam sintaks PBL. Kelemahan PBL yaitu siswa kesulitan dalam proses penyelesaian masalah (Yadav dkk, 2011). Selain itu, dalam pelaksanaannya PBL kurang efektif dan efisien karena PBL berpotensi membebani siswa, dimana siswa hanya memiliki sedikit waktu untuk belajar mandiri (Cheong, 2008; Sahin, 2009). Oleh karena itu, pelaksanaan PBL harus disertai dengan 
adanya unsur scaffolding yang disesuaikan dengan tujuan pembelajaran yang akan dicapai agar pelaksanaannya menjadi efektif (Jonassen, 2011; Masek dan Yamin, 2011).

Ada beberapa macam scaffolding yang bisa digunakan dalam pembelajaran. Menurut Hannafin,dkk (1999) scaffolding diklasifikasikan menjadi empat kategori berdasarkan fungsinya: conceptual scaffolding, metacognitive scaffolding, procedural scaffolding, dan strategic scaffolding. Conceptual scaffolding merupakan scaffolding yang diberikan untuk mendukung pemikiran siswa mengenai suatu informasi, ide, dan teori yang diberikan dalam lingkungan pembelajaran. Metacognitive scaffolding menunjukkan bagaimana menangani cara berpikir siswa selama pembelajaran. Procedural scaffolding adalah scaffolding yang menghadapkan siswa pada peralatan yang tersedia di lingkungan pembelajaran. Tipe-tipe scaffolding ini membantu siswa dalam memahami petunjuk untuk menyelesaikan masalah dalam pembelajaran. Strategic scaffolding adalah scaffolding untuk mempromosikan analisis, perencanaan, pengambilan keputusan selama pembelajaran, metode pemisahan dan pemilihan informasi yang digunakan untuk menghubungkan pengetahuan sebelumnya dan pengetahuan baru.

Diantara keempat jenis scaffolding tersebut, yang paling sesuai untuk diterapkan dalam pembelajaran fisika khususnya model PBL adalah procedural scaffolding. Hal ini disebabkan karena PBL merupakan pembelajaran berbasis masalah dimana siswa dihadapkan dengan suatu permasalahan yang harus diselesaikan baik secara individu maupun kelompok,

sedangkan

procedural scaffolding sendiri merupakan bantuan yang diberikan untuk membantu siswa dalam proses pemecahan masalah. Seperti penelitian yang dilakukan oleh Ge \& Land (2003) tentang efek dari petunjuk pertanyaan dan interaksi dengan teman sebaya sebagai scaffolding dalam proses pemecahan masalah dalam tugas terstruktur. Hasil penelitian ini mengungkapkan bahwa petunjuk pertanyaan sebagai salah satu bentuk procedural scaffolding memiliki efek positif secara signifikan terhadap kinerja siswa dalam pemecahan masalah dan interaksi dengan teman sebaya menunjukkan pengaruh yang signifikan terhadap hasil belajar. Penelitian Tiantong (2013) juga mengungkapkan bahwa dari 4 jenis modul (conceptual scaffolding, metacognitive scaffolding, procedural scaffolding, dan strategic scaffolding), yang paling efektif untuk digunakan pada pembelajaran PBL adalah modul dengan procedural scaffolding. Procedural scaffolding dapat digunakan dalam proses PBL yaitu untuk membantu siswa dalam proses menyelesaikan masalah (Tiantong, 2013). Menurut Choo (2011), salah satu bentuk procedural scaffolding yang bisa diterapkan dalam PBL adalah lembar kerja dengan scaffolding berupa kalimat pernyataan dan bantuan pertanyaan.

Berdasarkan hasil penelitian di atas, penelitian ini dilakukan untuk mengembangkan model Problem Based Leraning sehingga dapat meningkatkan penguasaan konsep mahamahasiswa PGSD STKIP PGRI Tulungagung pada matakuliah Pendidikan SAINS SD.

\section{Metode Penelitian}


Jenis penelitian ini adalah penelitian pengembangan dengan menggunakan desain 4-D (Four D-Models) yang dikemukakan oleh Thiagarajan (1974). Adapun langkah-langkahnya yaitu (a) Define (Pendefinisian) terdiri atas analisis kurikulum, analisis mahasiswa, analisis konsep, analisis tugas, dan menetapkan tujuan pembelajaran, (b) Design (Perancangan) terdiri atas RPS, RPP, LKS berscaffold, dan lembar penilaian, (c) Develop (Pengembangan) yaitu draf yang sudah disusun dikonsultasikan secara bertahap dengan dosen PGSD dan Dosen IPA mengenai penggunaan bahasa, kalimat, format perangkat pembelajaran, tujuan, dan konsep yang kemudian disebut dengan draf I, (d) Disseminate (Penyebaran) yaitu bertujuan untuk menyempurnakan perangkat pembelajaran SAINS SD yang telah di desain (draf I) untuk menghasilkan perangkat pembelajaran yang telah direvisi oleh pakar, sehingga layak digunakan dalam uji coba tahap 2 .

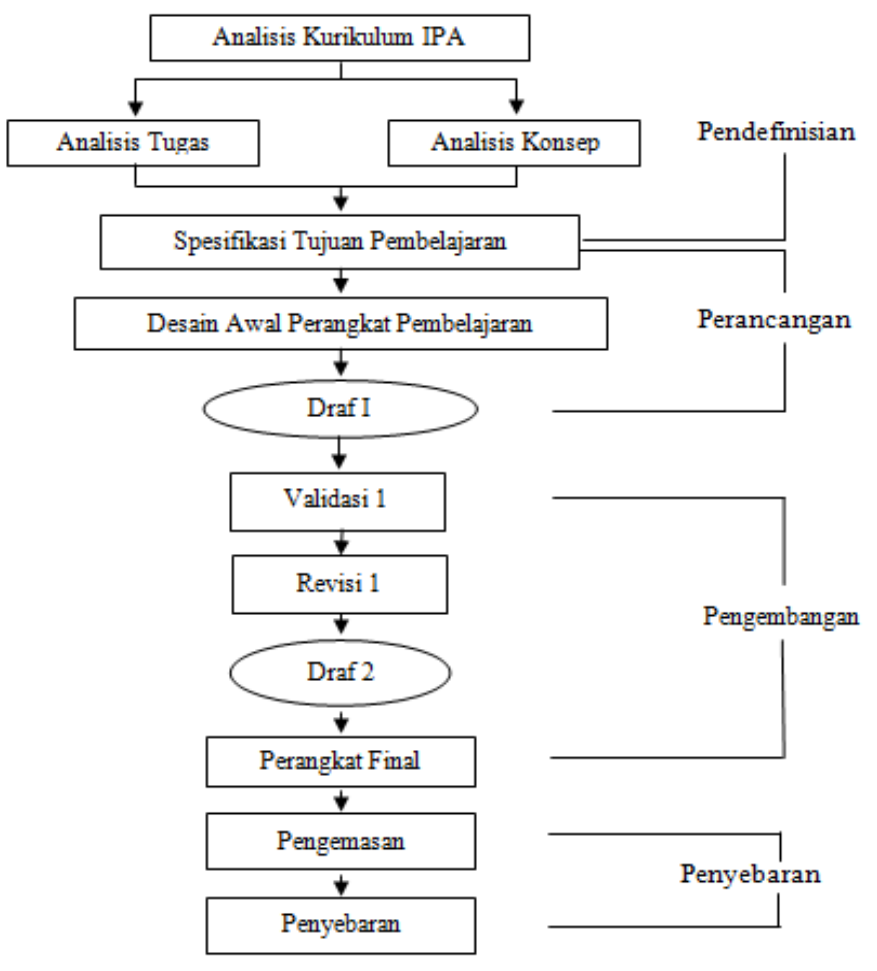

Gambar 1 Model Pengembangan Perangkat Pembelajaran Perangkat Model 4-D (Diadaptasi dari Ibrahim, 2002)

Penelitian ini hanya terbatas sampai pada tahap Develop, karena perangkat pembelajaran masih dalam tahap uji coba di dalam kelas, yaitu suatu bentuk pengembangan untuk menguji validitas yang digunakan. Penelitian ini mengambil lokasi penelitian di Program Studi PGSD STKIP PGRI Tulungagung.

Dalam penelitian ini metode yang digunakan adalah metode angket, metode validasi, dan metode tes. Perangkat pembelajaran sebelum digunakan dalam uji coba di kampus, maka dilakukan validasi terlebih dahulu oleh para ahli. Validasi perangkat pembelajaran diantaranya adalah validasi RPS, RPP, LKS, dan tes penguasaan konsep.

Perangkat pembelajaran divalidasi oleh dua orang pakar dan satu praktisi untuk memberikan penilaian sesuai dengan instrumen yang tersedia. Penilaian validasi RPS, RPP, dan LKS dapat dianalisis dengan kriteria skor rata-rata seperti pada Tabel 1.

Tabel 1 Kriteria Penilaian Validasi Silabus, RPP, dan LKS

\begin{tabular}{|c|c|}
\hline Skor Rata-rata & Kriteria \\
\hline $1,0-1,9$ & Tidak valid \\
\hline $2,0-2,9$ & Kurang valid \\
\hline $3,0-3,9$ & Cukup valid \\
\hline $4,0-5,0$ & Valid \\
\hline
\end{tabular}

(Diadaptasi dari Sridana, 2007)

Validasi tes penguasaan konsep dilakukan oleh para pakar dan praktisi untuk memvalidasi isi dan konstruksi soal. Validasi isi berkenaan dengan ketepatan 
alat evaluasi ditinjau dari segi materi atau isi pelajaran yang dievaluasi. Validasi konstruksi berkenaan dengan kesesuaian butir dengan indikator yang ditetapkan. Para pakar dan praktisi memberikan penilaian terhadap tes penguasaan konsep sesuai dengan instrumen yang tersedia. Kriteria penilaian analisis validasi soal terhadap skor rata-rata seperti pada Tabel 2.

Tabel 2. Kriteria Penilaian Validasi Soal

\begin{tabular}{|c|c|}
\hline Skor rata-rata & Kriteria \\
\hline $1,0-1,9$ & Tidak valid \\
\hline $2,0-2,9$ & Kurang valid \\
\hline $3,0-3,9$ & Cukup valid \\
\hline $4,0-5,0$ & Valid \\
\hline
\end{tabular}

(Diadaptasi dari Sridana, 2007)

Analisis respons mahasiswa terhadap LKS secara statistik deskriptif, yaitu dilakukan dengan menganalisis data yang diperoleh dari penilaian mahasiswa dari instrumen yang diberikan, selanjutnya data disajikan dalam bentuk diagram.

Hasil pretest dan posttest mahasiswa selanjutnya digunakan untuk menganalisis skor peningkatan tes dengan istilah peningkatan ternormalisasi rata-rata (the average normalized gain) $\langle\mathrm{g}\rangle$, yang didefinisikan sebagai perbandingan peningkatan rata-rata aktual $\langle\mathrm{G}\rangle$ terhadap peningkatan rata-rata maksimum, yang dapat dirumuskan sebagai berikut (Hake, 1999):

$\left\langle g>\equiv \frac{\%<G>}{\%<G>_{\max }}=\frac{\%<\mathrm{S}_{\mathrm{f}}>-\%<\mathrm{S}_{\mathrm{i}}>}{100-\%<\mathrm{S}_{\mathrm{i}}>}\right.$

Keterangan: $\left\langle\mathrm{S}_{\mathrm{f}}\right\rangle=$ rata-rata nilai posttest $\left\langle\mathrm{S}_{\mathrm{i}}\right\rangle=$ rata-rata nilai pretest

Kategori skor peningkatan atau gain $\langle\mathrm{g}\rangle$ dapat ditunjukkan pada Tabel 3.

Tabel 3 Kategori Gain Scores

\begin{tabular}{|c|c|}
\hline Gain scores & Kategori \\
\hline$(<\mathrm{g}>)<0,3$ & gain rendah \\
\hline $0,3<(<\mathrm{g}>)<0,7$ & gain sedang \\
\hline $0,7<(<\mathrm{g}>)$ & gain tinggi \\
\hline
\end{tabular}

Respons siswa terhadap proses belajar mengajar IPA berbasis pendekatan saintifik dengan model pembelajaran inkuiri terbimbing dianalisis dengan menggunakan skala Likert. Instrumen respon siswa disusun dalam bentuk itemitem berupa pernyataan dan diisi siswa dalam bentuk checklist. Untuk keperluan analisis kuantitatif, maka jawaban diberi skor. Skor yang diberikan seperti pada Tabel 4.

Tabel 4. Skala Sikap Respon Siswa

\begin{tabular}{|c|c|c|}
\hline Sikap & Keterangan sikap & Skor \\
\hline SS & Sangat Setuju & 4 \\
\hline S & Setuju & 3 \\
\hline TS & Tidak Setuju & 2 \\
\hline STS & Sangat Tidak Setuju & 1 \\
\hline
\end{tabular}

(Arikunto, 2013)

\section{Hasil dan Pembahasan}

Tahap perancangan (design) menghasilkan RPS, RPP, LKS draft 1 yang kemudian ditelaah oleh pakar dan akan masuk dalam tahap revisi. RPS, RPP, LKS yang telah direvisi selanjutnya divalidasi. Hasil validasi diperoleh rata-rata penilaian RPS untuk semua aspek sebesar 4,89. Hasil validasi RPP diperoleh rata-rata penilaian RPP untuk semua aspek sebesar 4,72. Hasil validasi LKS diperoleh ratarata penilaian LKS sebesar 4,79. Berdasarkan hal tersebut, dapat disimpulkan bahwa RPS, RPP, dan LKS yang dikembangkan adalah layak 
digunakan dengan beberapa saran perbaikan dari validator.

Hasil analisis respon mahasiswa terhadap LKS secara keseluruhan disajikan dalam bentuk diagram pada Gambar 2 .

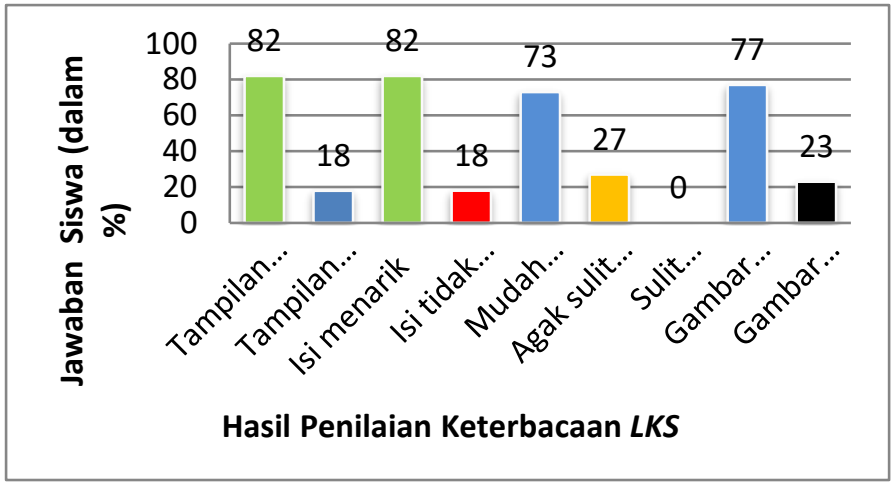

Gambar 2 Persentase Penilaian Respons

Mahasiswa terhadap LKS

Hasil perhitungan persentase respons mahasiswa terhadap LKS pada Tabel 2 dan digambarkan pada Gambar 2 menyebutkan tampilan LKS dan isi LKS dinilai responden menarik dengan persentase sebanyak $82 \%$; penjelasan LKS dinilai responden berada pada taraf mudah dipahami, agak sulit dipahami, dan sulit dipahami dengan persentase berturut-turut sebanyak $73 \%$, 27\%, dan 0\%; sedangkan gambar LKS dinilai responden berada pada taraf mudah dipahami dan sulit dipahami berturut-turut dengan persentase masingmasing $77 \%$ dan $23 \%$.

Persentase skor rata- rata hasil pretest dan posttest pada digunakan untuk menentukan peningkatan skor tes penguasaan konsep yang diuraikan secara ringkas pada Tabel 5.

Tabel 5. Skor Peningkatan Tes Penguasaan Konsep

\begin{tabular}{|c|c|c|c|c|c|}
\hline \multirow{2}{*}{ No. } & \multirow{2}{*}{ Siswa } & \multicolumn{2}{|c|}{ Skor (\%) } & \multirow{2}{*}{$\begin{array}{c}\text { Skor } \\
\text { Peningkatan }\end{array}$} & \multirow{2}{*}{ Kategori } \\
\cline { 3 - 4 } & & Pretest & Posttest & \\
\hline 1 & A & 40 & 85 & 0,75 & Tinggi \\
\hline 2 & B & 35 & 95 & 0,92 & Tinggi \\
\hline 3 & C & 45 & 90 & 0,82 & Tinggi \\
\hline 4 & D & 30 & 90 & 0,86 & Tinggi \\
\hline 5 & E & 35 & 85 & 0,77 & Tinggi \\
\hline 6 & F & 40 & 85 & 0,75 & Tinggi \\
\hline 7 & G & 55 & 95 & 0,89 & Tinggi \\
\hline 8 & H & 40 & 75 & 0,58 & Sedang \\
\hline 9 & I & 40 & 90 & 0,83 & Tinggi \\
\hline 10 & J & 50 & 80 & 0,60 & Sedang \\
\hline 11 & K & 40 & 85 & 0,75 & Tinggi \\
\hline 12 & L & 30 & 85 & 0,79 & Tinggi \\
\hline 13 & M & 40 & 85 & 0,75 & Tinggi \\
\hline 14 & N & 35 & 100 & 1,00 & Tinggi \\
\hline 15 & O & 60 & 100 & 1,00 & Tinggi \\
\hline 16 & P & 40 & 85 & 0,75 & Tinggi \\
\hline 17 & Q & 40 & 80 & 0,67 & Sedang \\
\hline 18 & R & 45 & 90 & 0,82 & Tinggi \\
\hline 19 & S & 55 & 90 & 0,78 & Tinggi \\
\hline 20 & T & 40 & 90 & 0,83 & Tinggi \\
\hline 21 & U & 50 & 80 & 0,60 & Sedang \\
\hline 22 & V & 30 & 85 & 0,79 & Tinggi \\
\hline & Rata- rata Skor Peningkatan & 0,79 & Tinggi \\
\hline
\end{tabular}

Berdasarkan data pada Tabel 5 diketahui bahwa dari sebanyak 22 mahasiswa diperoleh rata-rata skor peningkatan tes penguasaan konsep pada pertemuan 1 dan 2 sebesar 0,79 yang termasuk dalam kategori gain tinggi. Hal ini menunjukkan bahwa pembelajaran Pendidikan Sains SD berbasis procedural scaffolding dengan model pembelajaran Problem Based Learning dapat meningkatkan penguasaan konsep mahasiswa.

Respon mahasiswa terhadap pembelajaran SAINS dengan procedural scaffolding diperoleh dengan menggunakan instrumen angket. Angket respon mahasiswa diisi setelah keseluruhan kegiatan pembelajaran selesai. Data yang diperoleh disajikan secara ringkas pada Gambar 3.

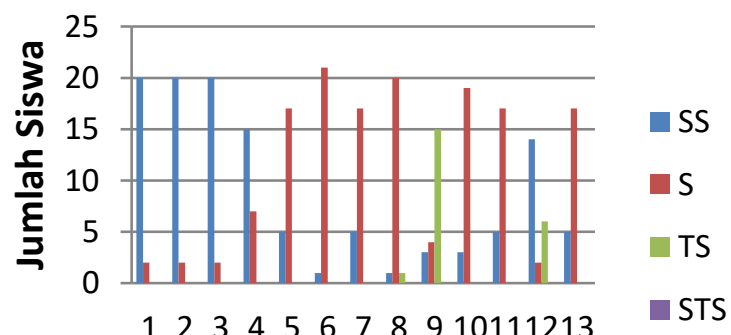

Pernyataan 


\section{Kesimpulan dan Saran}

Mengacu pada tujuan penelitian dan didukung dengan data hasil penelitian serta diikuti pembahasannya, maka dapat disimpulkan bahwa model Problem Based Learning dengan Procedural Scaffolding yang dikembangkan layak secara teoritis berdasarkan hasil validasi dari dosen diperoleh rata-rata penilaian RPS untuk semua aspek sebesar 4,89, hasil validasi RPP diperoleh rata-rata penilaian RPP untuk semua aspek sebesar 4,72, hasil validasi LKS diperoleh rata-rata penilaian LKS sebesar 4,79.

Berdasarkan hasil penelitian yang telah dilakukan, diperoleh saran- saran yaitu Dosen hendaknya menguasai materi, langkah-langkah pembelajaran, dan mengelola kelas dengan baik agar pembelajaran Problem Based Learning dengan Procedural Scaffolding dapat berjalan efektif, sehingga peningkatan penguasaan konsep mahasiswa dapat tercapai. Sebelum diadakan kegiatan praktikum, mahasiswa hendaknya diberikan pralab atau penjelasan mengenai alat dan bahan yang akan digunakan selama kegiatan praktikum sehingga dapat meminimalisir terjadinya kesalahan atau kecelakaan selama kegiatan praktikum berlangsung.

\section{Daftar Pustaka}

Arends, R. I. 2008. Learning to Teach (Belajar untuk Mengajar). Yogyakarta: Pustaka Pelajar

Demirel, M. \& Turan, B.A. 2010. The Effect of Problem Based Learning on Achievement, Attitude, Metacognitive Awareness and Motivation. Hacettepe Journal of Education 38: 55-66
Folashade, A \& Akinbobola, A.O. 2009. Constructivist Problem Based Learning Technique and the Academic Achievement of Physics Students with Low Ability Level in Nigerian Secondary Schools. Eurasian J. Phys. Chem. Educ. 1(1):45-51

Selcuk, G.S. 2010. The Effects of Problem-Based Learning on PreService Teachers' Achievement, Approaches and Attitudes Towards Learning Physics. International Journal of the Physical Sciences Vol.5(6), pp. 711-723

Bilgin, I., Senocak, E., Sozbilir, M. 2009. The Effects of Problem-Based Learning Instruction on University Students' Performance of Conceptual and Quantitative Problems in Gas Concepts. Eurasian Journal of Mathematics, Science \& Technology Education, 2009, 5(2), 153-164

Pepper, C. 2009. Problem Based Learning in Science. Issues in Educational Research, 19 (2)

Dolmans, D. H. J. M., \& Schmidt, H. G. (2006). What do we know about cognitive and motivational effects of small group tutorials in problem-based learning? Advances in Health Sciences Education, 11(4), 321-336.

Hedge, Balasubrahmanya. \& Meera, B.N. 2010. How Do They Solve It? An Insight Into The Learner's Approach to The Mechanism Of Physics Problem Solving. Physical Review Special TopicsPhysics Education Research 8, 010109 
Gonen, S. \& Basaran, B. 2008. The New Method of Problem Solving in Physics Education by Using Scorm-Compliant Content Package. Turkish Online Journal of Distance Education (TOJDE), 9(3): 112-120.

Yadav, A., Subedi, D., Lundeberg, M.A., \& Bunting, C.F. 2011. Problem Based Learning: Influence on Students Learning in an Electrical Engineering Course. Journal of Engineering Education April 2011, Vol.100, No.2, pp. 253-280.

Cheong, F. 2008. Using a problem-Based Learning Approach to Teach an Intelligent Systems Course. Journal of Information Technology Education Vol.7

Sahin, M. 2009. Exploring University Students' Expectations and Beliefs about Physics and Physics Learning in a Problem-Based Learning Context. Eurasia Journal of Mathematics, Science \& Technology Education, 2009, 5(4), 321-333

Jonassen, D. 2011. Supporting Problem Solving in PBL. Interdisciplinary Journal of Problem-based Learning Vol. 5 Issue 2

Masek, A., \& Yamin, S. 2011. The Effect of Problem Based Learning on Critical Thinking Ability: A Theoretical and Empirical Review. International Review of Social Sciences and Humanities Vol.2, No.1 (2011), pp. 215-221.

Hannafin, M., Land, S., \& Oliver, K. (1999). Open learning environments: Foundations, methods, and models. In M. R. Charles (Ed.), Instructional- design theories and models: A new paradigm of instructional theory (Vol. 2, pp. 115-140). Mahwah, NJ: Lawrence Erlbaum. Ge, X., \& Land, S. M. (2003). Scaffolding students' problem-solving processes in an ill-structured task using question prompts and peer interactions. Educational Technology Research \& Development, 51(1), 21-38.

Tiantong, M., \& Teemuangsai, S. 2013. The Four Scaffolding Modules for Collaborative Problem-Based Learning through the Computer Network on Moodle LMS for the Computer Programming Course. International Education Studies; Vol. 6, No. 5; 2013

Choo, S.S.Y., Rotgans, J.I., Yew, E.H.J., Schmidt, H.G. 2011. Effect of worksheet scaffolds on student learning in problem-based learning. Adv in Health Sci Educ (2011) 16:517-528 DOI 10.1007/s10459-011-9288-1

Ibrahim, M. (2002). Pelatihan Terintegrasi Berbasis Kompetensi Guru Mata Pelajaran Biologi Pengembangan Perangkat Pembelajaran. Jakarta: Departemen Pendidikan Nasional Sridana, N. (2007). Pengembangan Model Pelatihan untuk Penyusunan Rincian Materi Pengalaman Belajar Matematika bagi Guru Kelas VII melalui Penerapan Kriteria Pemilihan yang Berbasis Konstruktivisme. Disertasi Pendidikan Matematika, Universitas Negeri Surabaya. Arikunto, S. (2013). Dasar-Dasar Evaluasi Pendidikan. Jakarta: Bumi Aksara. 
Hake, R. R. (1999). “Analyzing Change/Gain Scores". Woodland Hills. Diakses melalui http://physics.indiana.edu/ sdi/anal yzingchange_gain.pdf: tanggal 2 Mei 2014. 